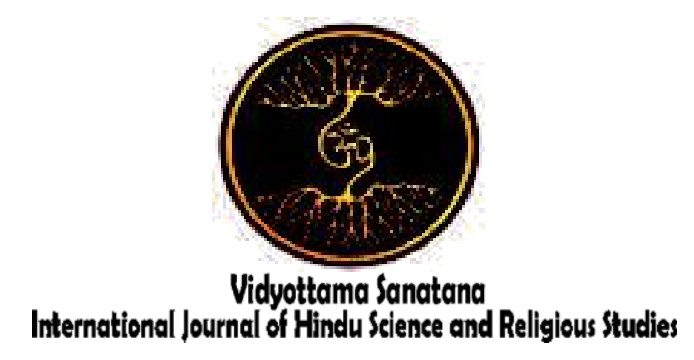

Vol. 2 No. 1 May 2018

\title{
The Discourse Of Ida Ratu Gede Mas Macaling Dalem Nusa Penida Klungkung (Position, Function and Meaning)
}

By:

I Made Dian Saputra ${ }^{1}$, I Nyoman Suarka ${ }^{2}$, I Nengah Sudipa ${ }^{3}$, I Wayan Cika ${ }^{4}$

${ }^{1}$ Institut Hindu Dharma Negeri Denpasar, ${ }^{23}{ }^{4}$ Universitas Udayana

E-mail: ${ }^{1}$ dektonk85@yahoo.com, ${ }^{2}$ tuarik4@yahoo.com, ${ }^{3}$ nengahsudipa@yahoo.co.id

\begin{tabular}{l|l|l} 
Received: Pebruary 14, 2017 & Accepted: May 15, 2018 & Published: May 31, 2018
\end{tabular}

\begin{abstract}
Hindus community in Bali views time as an important matter. The presence of time or Kala is associated with the myth of Magic. The relationship can be seen in the myth of Sasih Ka-enem which is believed to be the phase of epidemic. Often the myth of Sasih Ka-enem is also associated with the discourse of Ida Ratu Gede Mas Macaling as the magi figure of propagator and disaster in Bali. Interestingly, the image of Ida Ratu Gede Mas Macaling Dalem Nusa Penida just seems to be a living myth and "offerings" for balian, pengiring, and mysticism. Recently, many people perceive him as an object of worship, and more various interesting versions of Magi discourse about him growing in society. Because of those reasons, it is important to study the phenomenon into this scientific writing to identify the value and meaning of Magi discourse.
\end{abstract}

Keywords: Ida Ratu Gede Mas Macaling Discourse, Mystic, Magi, Sakti

\section{Introduction}

Time in Old Javanese is frequently referred to as Kala (Zoetmulder, 2004: 322). Then for the Balinese, it is often referred to Sang hyang Kala which actually refers to the fact that such time has "maha" (humongous) power. In that sense, nothing can overcome the power of time. Time as Sang hyang Kala is so great that nothing is everlasting by time. Sang hyang Kala is so powerful written in 
Vedic Smrti stating that God is the time (..., aham kalo'smi, ...). The belief in how the role of time seems so strong in Hindus society in Bali. Especially if the time associated with the mythology figure of Ida Ratu Gede Mas Macaling Dalem Nusa Penida, a figure who was born at a time and spread out epidemic/merana at the time of Sasih $\mathrm{Ka}$ enem. Sasih Ka-enem or the precise month of entering the Balinese sixth count is believed to be a month filled with disasters and pestilences so that in that sasih/month, Hindus Community execute Nangluk Merana rituals.

Nangluk Merana Ritua lin Sasih Kaenem is performed in all desapa kraman in Bali. It is commonly held with the ceremony of Pecaruan at village boundary with the aim at neutralizing the miserable sent by Ida Ratu Gede Mas Macaling Dalem Nusa Penida Klungkung. Many discourses are evolving in the social environment, that Ida Ratu Gede Mas Macaling Dalem Nusa Penida figure is a creepy figure and he spreads miserable to Bali (Saputra, 1998: 14). However, there are also other versions regarding his discourse as dewaning taksu balian, undagi, and other taksu.

The existence of various versions of it seems to be something interesting to be studied based on the study of discourse. More interestingly, Ida Ratu Gede Mas Macaling is not only Identified with the creepy figure (aeng) as an epidemic spreader, but also it is often used as an object of worship for any profession. Lately, not only the balian, undagi and mysticism who make him as the object of worship, but also from various communities come to Pura Dalem Ped to beg for the grace of taksu, magi, and sakti.

In this regard, it is interesting to examine the discourse of Ida Ratu Gede Mas
Macaling Dalem Nusa Penida as a discourse containing coherent values of taksu, magi and sakti. Based on the previous explanation, the discourse analysis is specified in the area of taksu, magi and sakti.

\section{DISCUSSION}

\subsection{The Discourse Position of Ida Ratu}

\section{Gede Mas Macaling in the Social} Environment of Bali Society

Before examining deeply the meaning of taksu, magi, and sakti in the discourse of Ida Ratu Gede Mas Macaling, it is firstly described the position of the discourse in the social environment of Hindus society in Bali. As mentioned earlier, there are various versions related to the discourse or myth of Ida Ratu Gede Mas Macaling in the religious dynamics of Balinese society. The variety of these versions can be found in literary discourse and oral discourse. All of these versions appear as if they are "living myths" which still exist in the social environment of Bali. This myth is regarded as an emesis that actually contains empirical truths so that the myth is not merely a myth but magi discourse which is interconnected to theologies and philosophical studies in a strong meaning (Atmaja, 2008: 87). Further,Ida Ratu Gede figure is believed to be real and not just the discourse of fiction in the literary space.

The diversity of the literary discourse version can be found in Saputra's description (2008: 9), that there are two sources of lontar (manuscripts) that tell the genealogical figure of Ida Ratu Gede Macaling, such as the text in lontar Ratu Gede Macaling (collection of Unud Linguistic Faculty (now is called Cultural Science Faculty), Ida RatuGede Mas Macaling is the same as Dalem Dukut. It is mentioned in Babad Belahbatuh 
(GedongKertya's collection, unrecorded number), and "Babad Dalem", which tells of Gelgel troop attack to Nusa Penidaand there is no literal sourceis found which mention or describe Ratu Gede Macaling figure in another name of Dalem Nusa. Even though, these two traditional historical texts do not purify themselves from the bond of supernatural powers, for example, the Magical power of kris used to kill Dalem Nusa actually originates from Bhatara in Toh Langkir (Mount Agung), but there is no writing of Dalem Nusa's niskala threat to the Bali population as described in lontar of Ratu Gede Macaling which is not classified as a history text. Also, in both chronicles, no narratives of supernatural powers are found to lead to the use of black Magic as described in the folklore, which is then perceived as such by the Balinese generally (Saputra, 2008: 13).

The next version, Babad Nusa Penida (in JeroMangku Made Buda version) narrates quite similarly with "Lontar Dukuh (p.7) Jumpungan" actually tells the genealogy of Ida Ratu Gede Macaling figure as an ordinary human being, a son of I Renggan with $N i$ Merahim. Ni Ratu Gede Macaling was born in Saka 180, while her sister Ni Tole was born in Saka 185. Ni Tole is married by Dalem Sawang who became a king in Nusa. If it is connected with "Babad Dalem" and "Babad BelahBatuh", it is clear that Dalem Sawang is not DalemNusa who was attacked by Gelgel's troops. There are two reasons why the two characters are different. First, Dalem Nusa or Dalem Bungkut is a descendant or a close relative of Dalem Di Made, while Dalem Sawang is the king of Nusa who ruled in a time very far apart from the reign of Dalem Nusa or Dalem Bungkut (Saputra, 2008: 14).
Furthermore, the diversity of versions is also found in oral discourse. In the oral discourse of the story there is almost a resemblance, there is even a mixture of stories in the narration in Lontar Ratu Gede Mas Macaling with the text in Babad Dalem Nusa. Thus there is interpolation resulting in a new discourse. Nevertheless, each version always shows a Magi narrative that tends to be creepy. The diversity of the version seems not to be an important thing because when referring to Ida Ratu Gede Mas Macaling must refer to the Magi and mystical things. In relation to this matter, Ida Ratu Gede Mas Macaling's position of discourse is in fact very important as "Magi discourse" which is related to the occult and creepy inclinations. As Ghazali (2011: 130) states that Magi is where the world is filled with supernatural powers.

\subsection{The Discourse Function of Ida Ratu} Gede Mas Macaling in the Social Environment Of Bali Society

Literal and oral discourse have different and diverse functions. This function is related to the discourse that develops in the social environment and depends on the emiks of the society in which the discourse develops. In regard to the discourse function of Ida Ratu Gede Mas Macaling Dalem Nusa Penida Klungkung which is relevant referring to the function theory of Malinowski a social anthropologist, and he is interested in the myths and discourses of primitive people. Based on that reason, he assumes theoretically that discourse and myth can serve as a medium to humans that occultation as truly real in life, supernatural power is the basis of the religious life (Ghazali, 2011). Similarly, Frazer (1854-1941), a British 
folklore expert (in Koentjaraningrat, 1987: 43), states that when a man cannot solve problems of life with reason, he can solve them by supernatural. According to Frazer, the supernatural is all human action (or abstention from the action) to achieve a purpose through the forces that exist in nature as supernatural.

Based on the description, the discourse of Ida Ratu Gede Mas Macaling can be expressed as a discourse that serves to strengthen the belief towards unseen. It is because the discourse explicitly states that he is a figure or image that represents from how the magical power is working so that it can spread miserable on Sasih Ka-enem. Furthermore Malinowski also mapped that discourse and myth can also be used as a religious function in strengthening the belief in the forces of nature.

\subsection{The Discourse Meaning of Ida Ratu} Gede Mas Macaling

The meaning of the discourse of Ida RatuGede Mas Macaling is related to the narrative of discourse, both literal and oral, which refers to a magi and frightening incident. Then behind the narrative, it implicitly contains some deep meaning. Thus, the discourse is not merely a myth but contains deep meaning related to some important aspects of living. In addition, Ida Ratu Gede's discourse both in literal and oral discourse is a symbol in which there is a meaning that needs to be revealed. Referring to Endraswara (2010: 98) that literary discourse is nothing but a symbolic message contained meaning in it, and the success of a discourse is when the researcher able to reveal the message.
Based on that, the discourse of Ida Ratu Gede Mas Macaling is a symbol of the struggle of magi ideology of belief in the diverse system of Tantra Bhairawa. Because according to Avalon (2013: 21); Kiven (2016: 95), that the teachings of Tantra Bhairawa are related to the mythical worship of a ghastly figure. The scary figure is presented as a representation of the times and the magic associated with the worship of the Tanrisme version. Based on that, it can be argued that the figure of Ida Ratu Gede Mas Macalingis a symbolic figure of an ism that contains the secret doctrinal Tantra. Confidentiality of the teachings is poured in a symbolic discourse. For only by symbols can reveal the deepest aspect of reality that is not reached by the Indira. Accordingly, Eliiade states that symbols, myths, and rites always reveal a human boundary situation, and not just historical boundaries (Dibyasuharda, 1990: 25).

Referring to the explanation above, here are some descriptions related to the meaning contained in the discourse of Ida Ratu Gede Mas Macaling, as follows.

\subsubsection{The Meaning of Taksu}

Listening to the narrative of the discourse of Ida RatuGede Mas Macaling, both literary and oral, it can be known that Ida Ratu Gede is the master of all kinds of taksu. As quoted by Wirawan (2017: 63), that on the grace of Bhatara Kala Rudra (Sang Siwa Ludra), Ida Ratu Gede Mas Macaling received PancaTaksu's grace, namely: Taksu Balian, gering repellent, taksu kemeranaan, magic taksu and taksu pengeger. In oral discourse, it is also almost the same, according to JeroMangkuKaler (interviewed, August $25^{\text {th }}, 2017$ ) stated that Ida RatuGede 
was the image of Bhatara Kala Ludra as dewaning all taksu. Not only Taksu Balian, gering repellent, taksu kemeranaan, magic taksu and taksupengeger, but also all professions so that metaksu can invoke His grace.

Many experts described the theoretical terms with regard to Taksu. Taksu in The Balinese language can be interpreted as abstract and concrete. The next meaning is the power or the ultimate energy to enhance intellect, and Taksu in the sacred building is a place of family worship (Dibia, 2012: 31). Another meaning of Taksu can be interpreted as the top energy derived from God that can be obtained through ritual (ritual) and spiritual exercise. Furthermore, the word in Old Javanese approaching from taksu is caksuh, meaning eye (Zoetmulder, 1983: 153). It can be paralleled that the presence of taksu can be perceived and captured through the use of perceptual organs, so taksu is actually anything related to spiritual power. Based on the term taksu, the discourse of Ida Ratu Gede Mas Macaling actually contains a symbolic message, that when willing to metaksu or have spiritual power, one should train himself with things related to tapa-vrtayoga-samadhi or "spiritual thought."

Referring to the discourse of Ida Ratu Gede Mas Macaling, it is clear that to get the grace of panca taksu and sarwa taksu, He, of course, should do tapa-brata-yoga-samadhi. So, only through spiritual practice in behavior and denoting the path of self-denial, the taksuwill appear in the self. Later many people worshiped Ida Ratu Gede Mas Macaling and merely used as objects of worship. It is very rare that there are people who imitate spiritual sadhana, so that later he only worship euphoria. The important message through the discourse of Ida Ratu Gede Mas Macaling about the meaning of taksu is a spiritual power that can lift people from papa and klesa, and taksu will be obtained when sadhaka do sadhana as Ida Ratu Gede Mas Macaling.

\subsubsection{The Meaning of Magi}

Besides the meaning of taksu, Ida Ratu Gede Mas Macaling discourse also contains the meaning of magi. Magi as described in the description of Ghazali (2011: 130) that is all things related to occultation. Invisibility or magic can be used, and in the study of Anthropology, magic is the basis of religious beliefs. Koentjaraningrat (1987: 97) cited the description of R. H. Codrington that magic comes from a term "mana". "Mana" is a magical power that comes from God and in a person. The person who owns it is the person who always succeeds in his work, in gardening, in hunting, or in fishing and other work. Referring to the description, it is possible that the same as taksu is the unseen spirit.

The meaning of magi is clearly seen in the discourse of Ida Ratu Gede Mas Macaling. The magic depicted in the discourse is the message of the marker that human should strengthen the belief in the unseen. Later the influence of postmodernity has distorted the supernatural, and Ida Ratu Gede's discourse is actually a symbolic message for us to return to the supernatural as the power of the universe. However magic is the oldest form of religion. According to Marett (1997), the thought process that associates a force that causes the living being to move is magic. In addition, Marett proposes his own theory of the origin of human religion, namely that the base of 
religion is an "emotion" or a "vibration of the soul" arising from the admiration of man against certain things and symptoms that are extraordinary or unseen.

The discourse of Ida Ratu Gede Mas Macaling as a magic discourse containing religious messages that encourage the emotion and vibration of the human soul against symptoms that have supernatural characteristics. Most Balinese people, when Ida Ratu Gede Mas Macaling figure hearing there must be a vibration of the soul against the occult phenomena. That is, the discourse of Ida Ratu Gede is actually a lighter for humans and Hindus in Bali to grow the spirit (taksu).

\subsubsection{The Meaning of Sakti}

The Meaning of Sakti in the discourse of Ida Ratu Gede Mas Macaling is associated with literary discourse containing an aesthetic or Lango value. This aesthetic or lango experience is associated with a sense of beauty in the self, so as to elicit sakti bhava. Saktivada is aesthetic characteristics that have characteristics as according to Zoetmulder (1983: 203-218), include:

(1) Before making something, the creator worships God first; (2) To be one with God is both means and purpose; (3) the creation of works of art is yoga; (4) in the context of yoga, the author is a tool; (5) for the creator of the work of art to purify the emotion to become a sensation with spiritual behavior; (6) aesthetic experience imaginable everywhere; (7) thus, the creators of art and nature unite in beauty; (8) it turns out that the artist's aesthetic experience is his drowning with God as saktibhava; and
(9) thus the work of art is a monument of dharma.

Referring to it, it clearly shows that Sakti bhava is an aesthetic experience experienced by someone who is immersed in a sense of beauty. The discourse of Ida Ratu Gede Mas Macaling both literary and verbal discourse certainly shows the beauty of the things associated with the unseen. The sense of beauty can only be felt if one is able to understand the aesthetic peculiarities through the aesthetic experience or Lango of any literary discourse. Then the sense of beauty in self as sakti bhava can bring shrdaya that is the peak of esthetic experience. Sukayasa (2007: 43) explains that the culmination of the aesthetic experience is the artist or art connoisseurs experience perception and forget themselves to reach the universal point that brings the highest happiness. Then saktibhava according to Subagia (2016: 89) can be identified from the expression of trance or "kerauhan" which shows the supernatural power of Ista Dewata.

Śakti or Śaktibhava in this context can be interpreted as "Śakti" in the sense of persistence and kawisésan, because the discourse of Ida Ratu Gede Mas Macaling, both literary and oral is always associated with wisesa connoted with supernatural powers. In this regard, Śaktibhava is just a diction to describe the peak of the aesthetic experience of a literary discourse that can give rise to Śaktiwisesa. This Śakti wisesa is indeed a force that can be used as an effort to neutralize the pervasive pestilent forces.

\section{Conclusion}

Based on the above description, it can be concluded that the discourse of Ida Ratu 
Gede Mas Macaling has a very important position in the religious life of Balinese society. It can be seen from the public perception of Ida Ratu Gede figure as an object of worship that gives the grace of pancataksu and sarwataksu. Then Ida Ratu Gede Mas Macaling'sdiscourse function can be functioned as a media of sanctification, magical function and religious function. Furthermore, the discourse of Ida Ratu Gede Mas Macaling contains a strong meaning related to taksu and magic, so that the discourse of Ida Ratu Gede Mas Macaling is a symbolic message of an ideology and Tantra Bhairawa's ism in exposing the secrecy of the unseen.

\section{References}

Atmaja, Jiwa. 2008. Leak dalam Foklore Bali. Denpasar: CV Bali Media Ahikarsa. Avalon, Arthur. 2013. Tantra the Sakti Power. USA. New York University Press.

Dibyasuharda.1990. Dimensi Metafisik Dalam Simbol Ontologi Mengenai Akar Simbol. Yogyakarta: UGM Yogyakarta.

Endraswara, Suwardi.2010. Metedologi

Penelitian Sastra. Yogyakarta: PustakaPelajar.
Ghazali, Muchtar Muhamad.2011. Antropologi Agama Upaya Memahami Keragaman Kepercayaan, keyakinan dan Agama. Bandung: ALFABETA.

Gunarta, I. K. (2017). Hindu Theology Of Tradition Ngerebeg In Desa Adat Tegal Darmasaba Badung Bali. Vidyottama Sanatana: International Journal of Hindu Science and Religious Studies, 1(1), 30-39.

Kiven, Lydya. 2016. Menelusuri Figur Bertopi Dalam Relief Candi Zaman Majapahit. Jakarta: Kepustakaan Populer Gramedia.

Koentjaraningrat.1987. Sejarah Antropologi I. Jakarta: Anggota IKAPI.

Saputra, Kanduk.2008. Mitos Ida Ratu Gede Macaling (dalamMajalah Taksu.2008.Edisi ke 233). Denpasar: Taksu Bali.

Sobur, Adi.2009. Teori Semiotika Sastra, Teoridan Aplikasinya. Yogyakarta: LKIS.

Subagia, I Made.2016. Ritual Tantrik Ngereh Dalam Budaya Bali. Denpasar: Pustaka Manik Geni. 